\title{
Assessment of the possibility of profiting from solar energy through the use of walls with external sheet metal cladding
}

\author{
Henryk Żelazny, ${ }^{1, *}$ \\ ${ }^{1}$ University of Bielsko-Biala, Institute of Civil Engineering, Willowa 2, 43-309 Bielsko-Biala, Poland
}

\begin{abstract}
The possibility of profiting from solar radiation through external walls was studied for an experimental, windowless livestock building. Temperature measurements on the wall surfaces were taken during winter, in two measuring series. On the first day, the average sol-air temperature on the outer surface of the east-facing wall was $7.4^{\circ} \mathrm{C}$ and was even up to $2.2{ }^{\circ} \mathrm{C}$ lower than temperature of the outdoor air which was 9.6 ${ }^{\circ} \mathrm{C}$. With the averaged temperature of inner surface of the wall reaching $21.3{ }^{\circ} \mathrm{C}$, heat transfer form the outside into the building was impossible. An identical tendency in temperature distribution on surfaces was noticed on the west-facing wall. In the second measuring cycle, the sun temperature on external wall surfaces increased significantly $-13.3{ }^{\circ} \mathrm{C}$ on the eastern side, and $14.1^{\circ} \mathrm{C}$ on the western side. They were noticeably higher than the outdoor air temperature which was $9.1{ }^{\circ} \mathrm{C}$. However, the high indoor surface temperatures on the eastern and western walls -21.2 ${ }^{\circ} \mathrm{C}$ and $21.0{ }^{\circ} \mathrm{C}$ respectively, proved that in this case too, the transfer of heat generated by the sun's radiation into the building was impossible. The tests results imply that we should exclude reheating the building with the heat from sun heat external walls during winter. However, a similar assessment including more measuring series and several objects, could be also be performed during interim seasons.
\end{abstract}

\section{Introduction}

Outdoor sources of heat gains are solar radiation through windows, walls and roofs, infiltration of heat through external dividing elements, and the natural infiltration of warmer air from the outside [1]. Heat generated by solar exposure and penetrating from the outside through the opaque building envelope, is a consequence of the difference between air and solar radiation temperature [2]. This sol-air temperature is the hypothetical outside air temperature, which would give the same rate of heat flow into the shaded surface of the wall as it would at a given outside air temperature if solar radiation was released on this surface [1]. It can be calculated from the following formula [3]

$$
t_{s}=t_{z}+A \cdot I \cdot \alpha_{z}^{-1}
$$

\footnotetext{
*Corresponding author: hzelazny@wp.eu
} 
where: $t_{z}$ - the outside air temperature, ${ }^{\circ} \mathrm{C} ; A$ - the absorption coefficient for dark wall surfaces; $I$ - the total incident radiation, $\mathrm{W} \cdot \mathrm{m}^{-2} ; \alpha_{z}$ - the outside surface heat penetration coefficient, $\mathrm{W} \cdot\left(\mathrm{m}^{2} \cdot \mathrm{K}\right)^{-1}$. Another form of the sol-air temperature formula — with the heat penetration coefficient replaced with heat absorption resistance on the outer surface is presented below [4]

$$
t_{o e}=t_{o a}+R_{s o} \cdot a \cdot I_{G}
$$

where: $t_{o a}$ - the outside air temperature, ${ }^{\circ} \mathrm{C} ; R_{s o}$ - heat absorption resistance on the outer surface, $\mathrm{m}^{2} \cdot \mathrm{K} \cdot \mathrm{W}^{-1} ; a$ - the solar radiation absorbency; $I_{G}$ - the solar radiation, $\mathrm{W} \cdot \mathrm{m}^{-2}$. Thus, the sol-air temperature is higher than the outside air temperature and if the indoor temperature is lower than the temperature outside, heat is transferred through the wall and brings energy gains inside the building [1]. This process complies with the second law of thermodynamics, which according to the Clausius Statement, can be formulated as follows: Heat cannot automatically transfer from a lower-temperature body to a higher-temperature body [5].

Scientific reports in this area allow tlisting the following facts:

1. The sol-air temperature - formulas (1) and (2) - is higher than the outside air temperature (Markus and Morris 1980, Przydróżny 1991).

2. Heat gains through the wall occur because the indoor temperature is lower than the outdoor temperature (Jones 2001).

3. Heat transfer happens automatically only from a warmer body to a cooler body (Szargut 2000).

Based on the above assumptions, a working hypothesis can be the following: If the solair temperature around the building is higher than the outside air temperature, it is possible to obtain heat gains from solar radiation through opaque walls during winter, at least in the air in the contact zone with the inner wall surface - given that the temperature on the outer surface of these walls is higher at least from the outer surface temperature.

The goal of this paper was to verify this hypothesis by means of instrumental studies of temperature distribution in the outer and inner wall surfaces in a windowless livestock building.

\section{Materials and methods}

The possibility of profiting from solar radiation through external walls was studied for an experimental, windowless livestock building, exhibiting constant bioheat gains throughout the whole year. It was located in southern Poland, in the county of Cieszyn. A building without windows was purposely selected, to avoid heat gains through glass elements that increase indoor air temperature during sunshine, and consequently, the temperature on the inner surfaces of the building shell. The supporting structure of the building was made of steel frames, and the curtain walls were made of wooden spatial elements, insulated with mineral wool. The heat transfer coefficient of these partitions was $0,44 \mathrm{~W} \cdot\left(\mathrm{m}^{2} \cdot \mathrm{K}\right)^{-1}$. The temperature on the inner and outer surface of the wall (in this paper, called the outer surface sol-air temperature) was measured by means of EMT-08 thermometer. Three measuring positions, equidistant from one another, were set at $1.5 \mathrm{~m}$ above floor level. The location of the thermometer probe on the outer side coincided with the measurement points on the inside of the partition. At each measuring position, the temperature of the wall surfaces was measured at five measurement points located on the circumference of a circle with a $0.5 \mathrm{~m}$ diameter, and in its center - Fig. 1 The outside air temperature was measured with a MM01 microclimate meter, located in the shade to avoid solar radiation affecting the 
measurements. The studies were performed in winter, in two measurement series on two sunny, cloudless days in February: at $3 \mathrm{pm}$ on the first day and at 9 am the following day. The speed of air movement in the room during the tests was in the range from 0,14 to 0,19 $\mathrm{m} \cdot \mathrm{s}^{-1}$, and on the outside it amounted to an average of $0,35 \mathrm{~m} \cdot \mathrm{s}^{-1}$. These values were so small that they could not have a significant impact on the results of temperature measurements on the surfaces of the walls.

\section{Results and discussion}

The temperature on the inner surface of the east-facing wall, measured in two series, is presented in Table 1. On the first day of measuring, the average values in certain measuring positions ranged from $21.2{ }^{\circ} \mathrm{C}$ to $21.4{ }^{\circ} \mathrm{C}$, and the outside air temperature was only $9.6{ }^{\circ} \mathrm{C}$. Similar differences were recorded the following day. The average temperature of the external surfaces of this wall ranged from $20.4{ }^{\circ} \mathrm{C}$ to $22.1{ }^{\circ} \mathrm{C}$, with the outside air temperature of $9.1{ }^{\circ} \mathrm{C}$. In these environmental conditions - given that the temperature field is one-dimensional and set - direct heat transfer from the outside into the livestock room through the eastern wall was impossible (if we exclude solar radiation and the high temperature of the outer wall surface resulting from the heating of the metal sheet cladding by the sunlight).

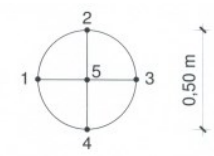

Fig. 1. Location of measurement points at each measuring position.

The measured and averaged temperature on the inner surface of the western wall on the first and second day of measurements are presented in Table 2. Compared to the outside air temperature, the values of this parameter were similarly distributed.

Tables 3 and 4 compare the temperature values measured on two days, at three measuring positions on the outer side of the east-facing and west-facing wall, respectively. Surprisingly, despite the sunny weather, the values recorded for both walls on the first day at $3 \mathrm{pm}$ (range from $7.1{ }^{\circ} \mathrm{C}$ to $7.6^{\circ} \mathrm{C}$ ) did not exceed the outside air temperature which was $9.6^{\circ} \mathrm{C}$. This cannot be explained by potential shading of the eastern wall in the afternoon and the lower temperature of its facade, because at $3 \mathrm{pm}$, the sun's exposure of the western wall also did not cause an increase in the temperature on its sheet cladding, compared to the outside air temperature. Most likely, the cladding might have cooled due to unfavorable thermal conditions (heavy clouds) in the period prior to the study.

Fig. 2 shows changes in the averaged temperature measured on the outer side of the eastern wall and the temperature on the inner surface of this wall. At each measuring position, the values on the external wall surface were much lower than the values on the inside. According to the second law of thermodynamics, energy as heat cannot be automatically transferred from cooler to warmer places. Therefore, we can clearly say that, given the conditions on the first day of measurement, solar heat gains through this wall were impossible to obtain. It is difficult to compare these results to the results of other studies. Scientific and technical literature provides analyses of heat gains only through modified walls, for example, a Trombe wall (a wall with a layer of air between a glass layer and load-bearing walls to obtain a greenhouse effect) in the context of the energy demand of buildings [6], or a multicomponent wall made of phase change materials [7]. The author is not aware of any reports evaluating the possibility of obtaining heat gains through opaque dividing elements. There are many research results published regarding heat transfer through windows [8-11]. As for windowless elements, the studies focus more on protecting 
buildings from superheating, especially through the roof [12-16], rather than on gaining solar heat inside.

Table 1. Temperature on the inner surface of the eastern wall and the averaged values of this parameter during the first and second day of measurements.

\begin{tabular}{|c|c|c|c|c|c|}
\hline \multirow{2}{*}{$\begin{array}{l}\text { Measuring } \\
\text { position } \\
\text { number }\end{array}$} & \multirow{2}{*}{$\begin{array}{l}\text { Number of } \\
\text { measuring point } \\
\text { in the position }\end{array}$} & \multicolumn{2}{|c|}{ First day of survey (3 pm) } & \multicolumn{2}{|c|}{ Second day of survey (9 pm) } \\
\hline & & $\begin{array}{c}\text { Surface } \\
\text { temperature } \\
{\left[{ }^{\circ} \mathrm{C}\right]}\end{array}$ & $\begin{array}{l}\text { Averaged } \\
\text { surface } \\
\text { temperature } \\
{\left[{ }^{\circ} \mathrm{C}\right]} \\
\end{array}$ & $\begin{array}{c}\text { Surface } \\
\text { temperature } \\
{\left[{ }^{\circ} \mathrm{C}\right]}\end{array}$ & $\begin{array}{l}\text { Averaged } \\
\text { surface } \\
\text { temperature } \\
{\left[{ }^{\circ} \mathrm{C}\right]} \\
\end{array}$ \\
\hline \multirow{5}{*}{1} & 1 & 21.5 & \multirow{5}{*}{21.2} & 20.2 & \multirow{5}{*}{20.4} \\
\hline & 2 & 21.3 & & 20.0 & \\
\hline & 3 & 20.8 & & 20.6 & \\
\hline & 4 & 21.1 & & 20.7 & \\
\hline & 5 & 21.3 & & 20.6 & \\
\hline \multirow{5}{*}{2} & 1 & 21.3 & \multirow{5}{*}{21.4} & 21.4 & \multirow{5}{*}{21.2} \\
\hline & 2 & 21.5 & & 21.1 & \\
\hline & 3 & 21.4 & & 21.0 & \\
\hline & 4 & 21.5 & & 21.6 & \\
\hline & 5 & 21.2 & & 21.0 & \\
\hline \multirow{5}{*}{3} & 1 & 21.2 & \multirow{5}{*}{21.4} & 21.8 & \multirow{5}{*}{22.1} \\
\hline & 2 & 21.3 & & 22.0 & \\
\hline & 3 & 21.4 & & 22.1 & \\
\hline & 4 & 21.6 & & 22.2 & \\
\hline & 5 & 21.5 & & 22.2 & \\
\hline
\end{tabular}

Table 2. Temperature on the inner surface of the western wall and the averaged values of this parameter during the first and second day of measurements.

\begin{tabular}{|c|c|c|c|c|c|}
\hline \multirow{2}{*}{$\begin{array}{l}\text { Measuring } \\
\text { position } \\
\text { number }\end{array}$} & \multirow{2}{*}{$\begin{array}{l}\text { Number of } \\
\text { measuring point } \\
\text { in the position }\end{array}$} & \multicolumn{2}{|c|}{ First day of survey $(3 \mathrm{pm})$} & \multicolumn{2}{|c|}{ Second day of survey $(9 \mathrm{pm})$} \\
\hline & & $\begin{array}{c}\text { Surface } \\
\text { temperature } \\
{\left[{ }^{\circ} \mathrm{C}\right]}\end{array}$ & $\begin{array}{l}\text { Averaged } \\
\text { surface } \\
\text { temperature } \\
{\left[{ }^{\circ} \mathrm{C}\right]} \\
\end{array}$ & $\begin{array}{c}\text { Surface } \\
\text { temperature } \\
{\left[{ }^{\circ} \mathrm{C}\right]}\end{array}$ & $\begin{array}{l}\text { Averaged } \\
\text { surface } \\
\text { temperature } \\
{\left[{ }^{\circ} \mathrm{C}\right]} \\
\end{array}$ \\
\hline \multirow{5}{*}{1} & 1 & 20.5 & \multirow{5}{*}{20.9} & 20.8 & \multirow{5}{*}{20.6} \\
\hline & 2 & 20.7 & & 20.6 & \\
\hline & 3 & 21.0 & & 20.6 & \\
\hline & 4 & 21.1 & & 20.6 & \\
\hline & 5 & 21.0 & & 20.4 & \\
\hline \multirow{5}{*}{2} & 1 & 21.8 & \multirow{5}{*}{21.8} & 21.0 & \multirow{5}{*}{21.1} \\
\hline & 2 & 21.7 & & 21.4 & \\
\hline & 3 & 21.9 & & 21.4 & \\
\hline & 4 & 21.9 & & 20.9 & \\
\hline & 5 & 21.9 & & 20.8 & \\
\hline \multirow{5}{*}{3} & 1 & 22.2 & \multirow{5}{*}{20.0} & 21.1 & \multirow{5}{*}{21.2} \\
\hline & 2 & 22.0 & & 21.2 & \\
\hline & 3 & 22.0 & & 21.4 & \\
\hline & 4 & 22.0 & & 21.3 & \\
\hline & 5 & 22.0 & & 21.2 & \\
\hline
\end{tabular}


Table 3. Temperature on the outer surface of the eastern wall and the averaged values of this parameter during the first and second day of measurements.

\begin{tabular}{|c|c|c|c|c|c|}
\hline \multirow{2}{*}{$\begin{array}{l}\text { Measuring } \\
\text { position } \\
\text { number }\end{array}$} & \multirow{2}{*}{$\begin{array}{l}\text { Number of } \\
\text { measuring point } \\
\text { in the position }\end{array}$} & \multicolumn{2}{|c|}{ First day of survey (3 pm) } & \multicolumn{2}{|c|}{ Second day of survey $(9 \mathrm{pm})$} \\
\hline & & $\begin{array}{c}\text { Surface } \\
\text { temperature } \\
{\left[{ }^{\circ} \mathrm{C}\right]}\end{array}$ & $\begin{array}{l}\text { Averaged } \\
\text { surface } \\
\text { temperature } \\
{\left[{ }^{\circ} \mathrm{C}\right]}\end{array}$ & $\begin{array}{c}\text { Surface } \\
\text { temperature } \\
{\left[{ }^{\circ} \mathrm{C}\right]}\end{array}$ & $\begin{array}{c}\text { Averaged } \\
\text { surface } \\
\text { temperature } \\
{\left[{ }^{\circ} \mathrm{C}\right]}\end{array}$ \\
\hline \multirow{5}{*}{1} & 1 & 7.3 & \multirow{5}{*}{7.3} & 13.1 & \multirow{5}{*}{13.2} \\
\hline & 2 & 7.3 & & 13.2 & \\
\hline & 3 & 7.3 & & 13.2 & \\
\hline & 4 & 7.3 & & 13.3 & \\
\hline & 5 & 7.3 & & 13.4 & \\
\hline \multirow{5}{*}{2} & 1 & 7.2 & \multirow{5}{*}{7.4} & 13.2 & \multirow{5}{*}{13.2} \\
\hline & 2 & 7.3 & & 13.1 & \\
\hline & 3 & 7.3 & & 13.2 & \\
\hline & 4 & 7.5 & & 13.2 & \\
\hline & 5 & 7.6 & & 13.4 & \\
\hline \multirow{5}{*}{3} & 1 & 7.4 & \multirow{5}{*}{7.4} & 13.2 & \multirow{5}{*}{13.5} \\
\hline & 2 & 7.3 & & 13.3 & \\
\hline & 3 & 7.3 & & 13.4 & \\
\hline & 4 & 7.4 & & 13.6 & \\
\hline & 5 & 7.4 & & 14.0 & \\
\hline
\end{tabular}

Table 4. Temperature on the outer surface of the western wall and the averaged values of this parameter during the first and second day of measurements.

\begin{tabular}{|c|c|c|c|c|c|}
\hline \multirow{2}{*}{$\begin{array}{l}\text { Measuring } \\
\text { position } \\
\text { number }\end{array}$} & \multirow{2}{*}{$\begin{array}{l}\text { Number of } \\
\text { measuring point } \\
\text { in the position }\end{array}$} & \multicolumn{2}{|c|}{ First day of survey $(3 \mathrm{pm})$} & \multicolumn{2}{|c|}{ Second day of survey $(9 \mathrm{pm})$} \\
\hline & & $\begin{array}{c}\text { Surface } \\
\text { temperature } \\
{\left[{ }^{\circ} \mathrm{C}\right]}\end{array}$ & $\begin{array}{c}\text { Averaged } \\
\text { surface } \\
\text { temperature } \\
{\left[{ }^{\circ} \mathrm{C}\right]} \\
\end{array}$ & $\begin{array}{c}\text { Surface } \\
\text { temperature } \\
{\left[{ }^{\circ} \mathrm{C}\right]}\end{array}$ & $\begin{array}{c}\text { Averaged } \\
\text { surface } \\
\text { temperature } \\
{\left[{ }^{\circ} \mathrm{C}\right]} \\
\end{array}$ \\
\hline \multirow{5}{*}{1} & 1 & 7.4 & \multirow{5}{*}{7.4} & 13.1 & \multirow{5}{*}{13.5} \\
\hline & 2 & 7.3 & & 13.3 & \\
\hline & 3 & 7.4 & & 13.7 & \\
\hline & 4 & 7.4 & & 13.8 & \\
\hline & 5 & 7.5 & & 13.8 & \\
\hline \multirow{5}{*}{2} & 1 & 7.4 & \multirow{5}{*}{7.3} & 13.5 & \multirow{5}{*}{13.5} \\
\hline & 2 & 7.3 & & 13.6 & \\
\hline & 3 & 7.2 & & 13.2 & \\
\hline & 4 & 7.3 & & 13.5 & \\
\hline & 5 & 7.2 & & 13.7 & \\
\hline \multirow{5}{*}{3} & 1 & 7.1 & \multirow{5}{*}{7.3} & 14.0 & \multirow{5}{*}{15.2} \\
\hline & 2 & 7.2 & & 13.7 & \\
\hline & 3 & 7.4 & & 15.8 & \\
\hline & 4 & 7.3 & & 15.7 & \\
\hline & 5 & 7.3 & & 16.8 & \\
\hline
\end{tabular}

During the second series of measurements, on the subsequent day in February, the average value of the sol-air temperature on the eastern wall cladding increased significantly, exceeding $13{ }^{\circ} \mathrm{C}$ (Fig. 3). This means it was much higher than the outside air temperature which was $9.1^{\circ} \mathrm{C}$, but it did not exceed the temperature of the inner surface. In 
this case, it was also impossible to gain heat from solar radiation, which could improve the building's heat balance during winter, even only to the layer of air adjacent to the inner surface of the wall (which had a slightly lower temperature than the outside air temperature).

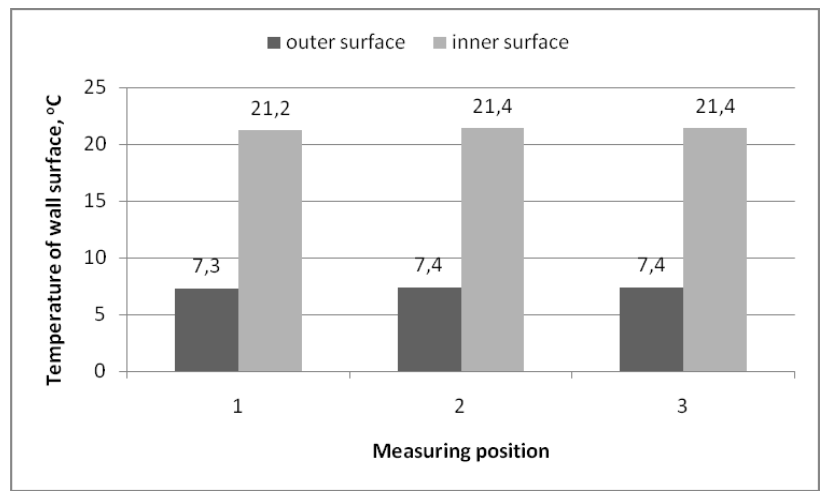

Fig. 2. Averaged temperature of the inner and outer surfaces of the east-facing wall at $3 \mathrm{pm}$ on the first day of measurement.

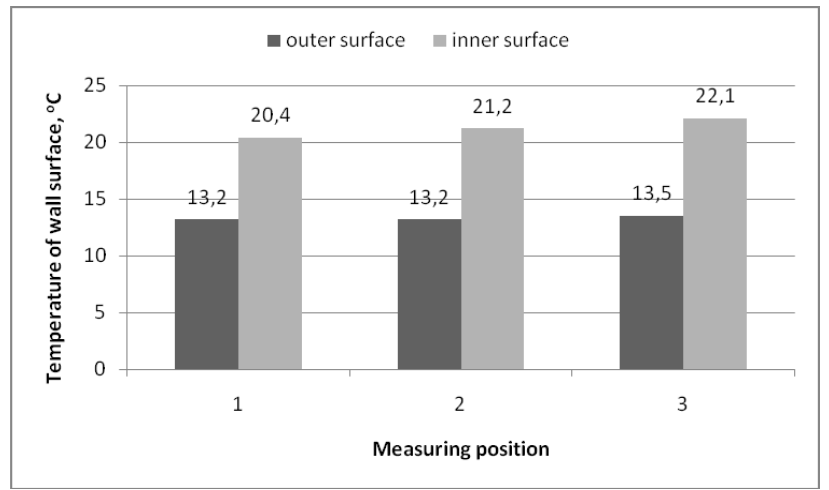

Fig. 3. Averaged temperature of the inner and outer surfaces of the east-facing wall at 9 am on the first day of measurement.

Fig. 4 presents the averaged values of the temperature on the inner and outer surfaces of the west-facing wall, recorded during first day of tests. The temperature distribution at the measuring positions on this wall during the second day of measurements is graphically shown in Fig. 5. The tendencies in temperature distribution on both surfaces were identical as for the eastern wall. During the first measuring series the inner surface temperature significantly exceeded the outer surface temperature (from $12.7^{\circ} \mathrm{C}$ to $14.5^{\circ} \mathrm{C}$ ), whereas on the second day, the difference was much smaller (from $6.0^{\circ} \mathrm{C}$ to $7.6^{\circ} \mathrm{C}$ ).

The presented results of measuring series temperature measurements on the inner and outer surfaces of both walls (eastern and western), lead to a clear conclusion that during winter, in Poland, one cannot expect additional heat gains from sunlight cast on external walls, or full dividing elements, in buildings with regulated and high inside air temperature. This additional source of heat cannot be included in the building's energy balance, even though in reports regarding Polish conditions, gains through opaque dividers are always included as positive sources [2, 17-19]. In the first measuring series, despite finishing with sheet metal cladding that easily heats up, temperatures on the outer surfaces of the vertical cladding of livestock building were even lower than the outside air temperature, and the temperature of the inner surfaces of these walls was about three times lower than the 
temperature on their outer surfaces. As for the second day, the sol-air temperature on the outer surfaces of the eastern and western wall exceeded the outside air temperature by about $4{ }^{\circ} \mathrm{C}$, yet the inner contact area of air and these walls was even warmer (over $20^{\circ} \mathrm{C}$ ). In these conditions too, the heat transfer from the contact surface with the outside air to the contact surface with the indoor air, and further heat flow by means of convection and radiation was impossible.

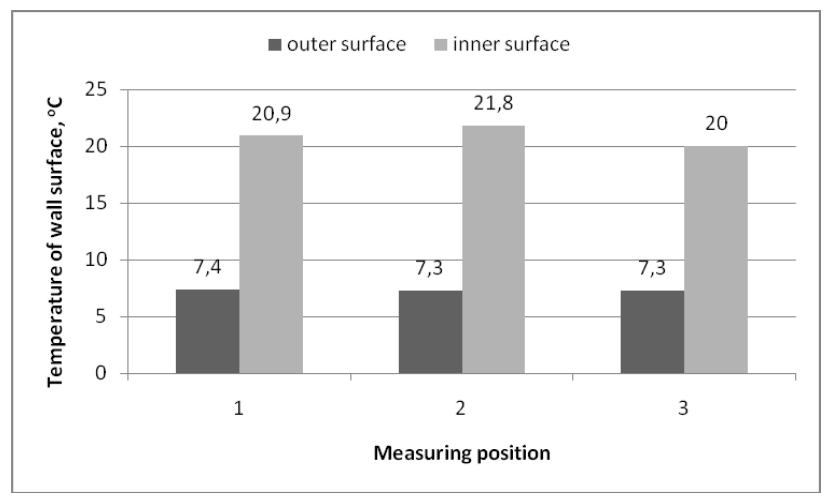

Fig. 4. Averaged temperature of the inner and the outer surfaces of the west-facing wall at $3 \mathrm{pm}$ on the first day of measurement.

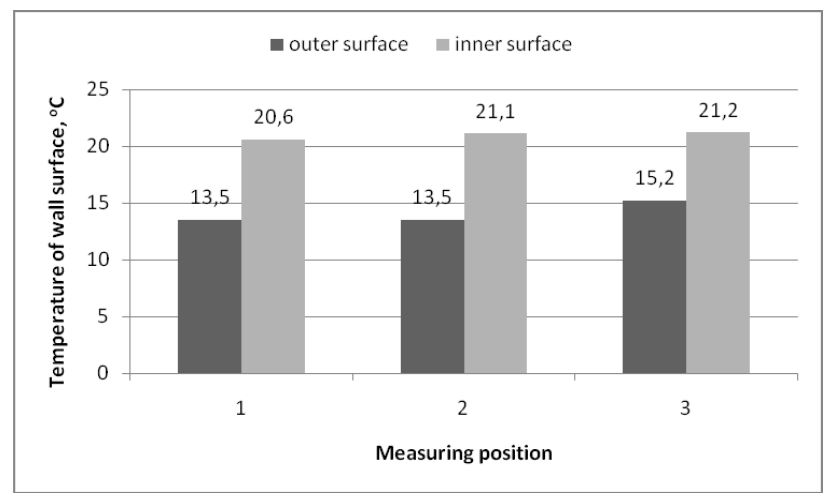

Fig. 5. Averaged temperature of the inner and the outer surface of the west-facing wall at 9am on the second day of measurement.

\section{Conclusions}

Based on the conducted studies, we can draw the following conclusions:

1. The sol-air temperature on the outer surfaces of the eastern and western walls of the studied building was lower than the temperature of the inner surfaces, and thus, reheating the building with solar heat absorbed through the walls is not possible.

2. To obtain more general results from instrumental tests of the possibility to gain heat through external walls heated by sunlight during cool days, similar studies would have to be conducted, involving more measuring series repeated in at least several objects covered with materials with different coefficients of solar radiation absorption.

3. An interesting problem is the scale of temperatures of the external wall in the interim seasons, when there is more sunlight than during winter. Therefore, studies could be continued in this direction in order to determine periods when for certain buildings the sol- 
air temperature on the external surface is higher than the temperature of the inner surface of the walls.

\section{References}

1. W.P. Jones, Klimatyzacja (Arkady, Warszawa, 2001)

2. T. Klinke, K. Krygier, J. Sewerynik, Ogrzewnictwo, wentylacja, klimatyzacja (WSiP, Warszawa, 1991)

3. S. Przydróżny, Wentylacja (Wydawnictwo Politechniki Wrocławskiej, Wrocław, 1991)

4. T.A. Markus, E.N. Morris, Buildings, climate, and energy, Pitman Pub., 1980

5. J. Szargut, Termodynamika techniczna (Wydawnictwo Politechniki Śląskiej, Gliwice, 2000)

6. P. Herbut, S. Angrecka, E. Herbut, G. Nawalany, P. Sokołowski, Analiza zysków ciepła $z$ helioaktywnych elementów $w$ budynku o konstrukcji szkieletowej, INFRASTRUKTURA I EKOLOGIA TERENÓW WIEJSKICH 1, 409-418 (2017)

7. K. Peippo, P. Kauranen, P.D. Lund, A multicomponent PCM wall optimized for passive solar heating, Energy and Buildings 17 (4), 259-270 (1991)

8. E.M. Alawadhi, Using phase change materials in window shutter to reduce the solar heat gain, Energy and Buildings 47, 421-429 (2012)

9. D. Feuermann, A. Novoplansky, Reversible low solar heat gain windows for energy savings, Solar Energy 62 (3), 169-175 (1998)

10. J.W. Lee, H.J. Jung, J.Y. Park, J.B. Lee, Y. Yoon, Optimization of building window system in Asian regions by analyzing solar heat gain and daylighting elements, Renewable Energy 50, 522-531 (2013)

11. D.G. Stephenson, Equations for solar heat gain through windows, Solar Energy 9 (2), 81-86 (1965)

12. R. Levinson, P. Berdahl, A.A. Berhe, H. Akbari, Effects of soiling and cleaning on the reflectance and solar heat gain of a light-colored roofing membrane, Atmospheric Environment, 40), 7807-7824 (2005)

13. R. Levinson, H. Akbari, P. Berdahl, Measuring solar reflectance - Part I: Defining a metric that accurately predicts solar heat gain, Solar Energy, 84 (9), 1717-1744 (2010)

14. J.A. Reagan, D.M. Acklam, Solar reflectivity of common building materials and its influence on the roof heat gain of typical southwestern U.S.A. residences, Energy and Buildings 2 (3), 237-248 (1979)

15. H. Suehrcke, E.L. Peterson, N. Selby, Effect of roof solar reflectance on the building heat gain in a hot climate, Energy and Building 40, 2224-2235 (2008)

16. L. Susanti, H. Homma, H.Matsumoto, Y.Suzuki, M.Shimizu, A laboratory experiment on natural ventilation through a roof cavity for reduction of solar heat gain, Energy and Buildings 40 (12), 2196-2206 (2008)

17. D. Chwieduk, Energetyka słoneczna (Arkady, Warszawa, 2011)

18. P. Klemm (red.), Budownictwo ogólne. T. 2 Fizyka budowli (Arkady, Warszawa, 2005)

19. S. Szcześniak, A. Sierota, Natężenie promieniowania słonecznego $w$ obliczeniach bilansu ciepła dla pomieszczeń, www.eko-dok.pl/2006/125.pdf [22.04.2018] 299-311 